\title{
IQCJ Gene
}

National Cancer Institute

\section{Source}

National Cancer Institute. IQCJ Gene. NCI Thesaurus. Code C98105.

This gene is involved in protein-protein interactions. 